\title{
Training Quality Teachers The Challenge of Design Skill
}

DOI: 10.47050/66515314.258-283

Laura Sara Agrati, Viviana Vinci

Designing teaching interventions is considered one of the main skills expected of teachers, a distinctive and peculiar trait of their profession. Learning design is linked to teaching as "the description of the teaching-learning process that takes place in a learning unit" and, as such, it is assumed as a concept, a description of specific sequences, but also as techniques used to realise these sequences. After recalling the characteristics of the main educational design models as well as the cyclical process of training teachers in design skills, the present chapter ${ }^{1}$ describes "Eurodesign" as an explanatory example of design skills, a topic of the Italian National Teaching Training Plan (2016-2019) and a priority of the European professional development system. It focuses on the didactic model of the professional course on "European Design in the school of autonomy" - the close connection between theory (design models) and practice (project activities) in the co-participated elaboration of real intervention devices (prototypes) through simulated experience.

\section{Keywords:}

design skill

teaching quality

European Design

$1 \quad$ Laura Agrati is the author of the sections "The design skill of teachers", "Quality training in design skills" and "Findings and conclusion" in this chapter. Viviana Vinci is the author of the section "Professional courses on design: The European Design case" and the subsection "Survey on teachers' representations of design". 


\section{The design skill of teachers}

Designing teaching interventions is considered one of the main skills expected of teachers (Law 13/07/2015, No. 107, European Commission, 2013), a distinctive and peculiar trait of their profession (Loughran, 2006; Laurillard, 2012; Snelbeker, 1987; Freiberg, 2002; Nikolaeva, 2012).

As a general rule, design refers to: a. an arrangement, "the general arrangement of the different parts of something that is made, such as a building, book, machine, etc". (Oxford, 2010, p. 411); b. a drawing/ plan/model, "the art or process of deciding how something will look, work, etc. by drawing plans, making models, etc". (Oxford, 2010, p. 411); c. a pattern, "an arrangement of lines and shapes as a decoration" (Oxford, 2010, p. 411); or d. an intention, in other words, a plan to do something.

Within the teaching and educational semantic field, the expression "learning design" indicates preparation (a), a drawing/a planning (b), and/or an intention (d). Although in English, within this context of meanings, it is often rendered with design, in Italian and French, progettare (lit. "throw forward", which highlights the forecasting component, the "intention", see (c) and planifier (lit. "make a plan", which rather emphasises the operational component, the "drawing/plan/model", see (b), respectively, are used more often.

The technical construct of learning design is inevitably connected to that of teaching design; it could be defined as "the description of the teaching-learning process that takes place in a learning unit (a course, a lesson or any other planned learning event)" (Koper, 2006, p. 78). Britain (2004) invites us to associate learning design with a concept, a description of specific sequences, or some techniques used to realise these sequences.

Regardless of the field of meanings, but on the basis of a linear pedagogical model, with technical rationality (Taba, 1962; Skinner, 1954), design can be considered an activity producing as its output the description of an artifact (such as a project) including sufficient information to build/create and meet specifications given in its input (such as aims, objectives, limitations to be respected) (Rossi \& Toppano, 2009, p. 57); it would be "a mental and/or material representation of an object/activity (such as a didactic action, an educational 
intervention)" (Rossi \& Toppano, 2009, p. 11), functional to its effective realisation.

ADDIE, an acronym for the five phases of instructional design, is a well-known and interactive but linear model (Branson et al., 1975):

Analyse - the collection of information on learners (e.g. how they access the content), the tasks to be completed and the general objectives of the project;

Design - project creation, meeting between information collected and didactic design models, advance explanations of how learning will take place;

Develop - the choice of activities to be implemented;

Implement - check if the materials are functional and appropriate for learners;

Evaluate - verify whether the materials allow the stability objectives (summative (e)) to be achieved and if it is possible to improve the entire process (formative (e)).

Walter Dick et al. (2005) developed an interactive and parallel version of ADDIE for instructional design: identifying the instructional goal; conduct an instructional analysis (e.g. what the student must be able to do to perform a certain task); analyse learners and contexts; write performance objectives (behaviours, conditions and criteria); develop an assessment instrument (e.g. use of pre-/post-testing); develop an instructional strategy (e.g. content presentation, student participation, assessment); select instructional materials; conduct a formative evaluation of instructions (areas for improvement); revise instructions; and conduct a summative evaluation.

The literature offers other descriptive models of instructional design for teachers ${ }^{2}$, such as "backwards design" and "active learning". The framework of backwards design (Wiggins \& McTighe, 1998, 2008), centered on the curriculum, indicates three moments:

2 Very often associated with the behaviour modification intervention in a military environment (Branson et al., 1975) and inspired by Skinnerian behaviorism and learning by program by B. Bloom and R. Mager, the instructional design was articulated on the basis of the learning areas (R. Gagne's "nine events"), the effectiveness of the teaching materials (M. Scriven), the presentation methods (D. Merrill), up to the increasing centrality of the media, intended both as technological tools and as a "learning environment" (Reiser \& Dempsey, 2012). 
1. identify the results desired (learning objective/outcomes);

2. determine acceptable levels of evidence (assessment and feedback);

3. plan learning experience and instruction (instructions).

Fink, from the active learning perspective of Mantyla (1999), notes some essential components of effective active learning activities in an online learning environment or classroom $(2003,2005)$ :

4. a definite beginning and ending (timing);

5. a clear purpose and a learning objective (learning objectives - outcomes);

6. complete and understandable directions (instructions - learning activities);

7. a plan for assessing the objective(s) and providing feedback to students (assessment and feedback);

8. a description of the technology or tool(s) used in the exercise (mediation).

The characteristics of the four models are summarised, using neutral language, in the following comparative table (Table 1).

Table 1. Comparison of the phases in the main design models

\begin{tabular}{c|c|c|c|c} 
PHASE & $\begin{array}{c}\text { ADDIE } \\
\text { (BRANSON ET AL., 1975) }\end{array}$ & $\begin{array}{c}\text { ADDIE II } \\
\text { (DICK ET AL., 2005) }\end{array}$ & $\begin{array}{c}\text { BACKWARDS } \\
\text { (WIGGINS \& MCTIGHE, 1998) }\end{array}$ & $\begin{array}{c}\text { ACTIVE LEARNING } \\
\text { (FINK, 2003) }\end{array}$ \\
\hline 1. & learning outcomes & learning outcomes & learning outcomes & timing \\
\hline 2. & learning outcomes & learning outcomes & assessment & learning outcomes \\
\hline 3. & instructions & learning outcomes & instructions & instructions \\
\hline 4. & assessment & learning outcomes & & assessment \\
\hline 5. & assessment & assessment & & mediation \\
\hline 6. & & instructions & & \\
\hline 7. & & mediation & & \\
\hline 8. & & assessment & & \\
\hline 9. & & assessment & &
\end{tabular}




\section{Quality training in design skills}

In 1987, Snelbecker was already referring to a "curious paradox": "despite expressions of concern about the quality of instruction offered in schools, and despite the existence of considerable research and theory in the instructional design literature which might be of value for teachers, there seems to be a "gap" between the teacher education literature and the instructional design literature" (p. 33). For this reason, the author focused on perspectives and problems "in helping teachers to learn and to use instructional design approaches and techniques" (Snelbecker, 1987, p. 33). From the point of view of the quality of teaching teachers, Frederik and Sonneveld $(2009$, p. 220; 2007) remarked that learning design "is usually described in literature as a cyclic process" (see Figure 1).

Figure 1. The "cyclic process" of the learning quality design

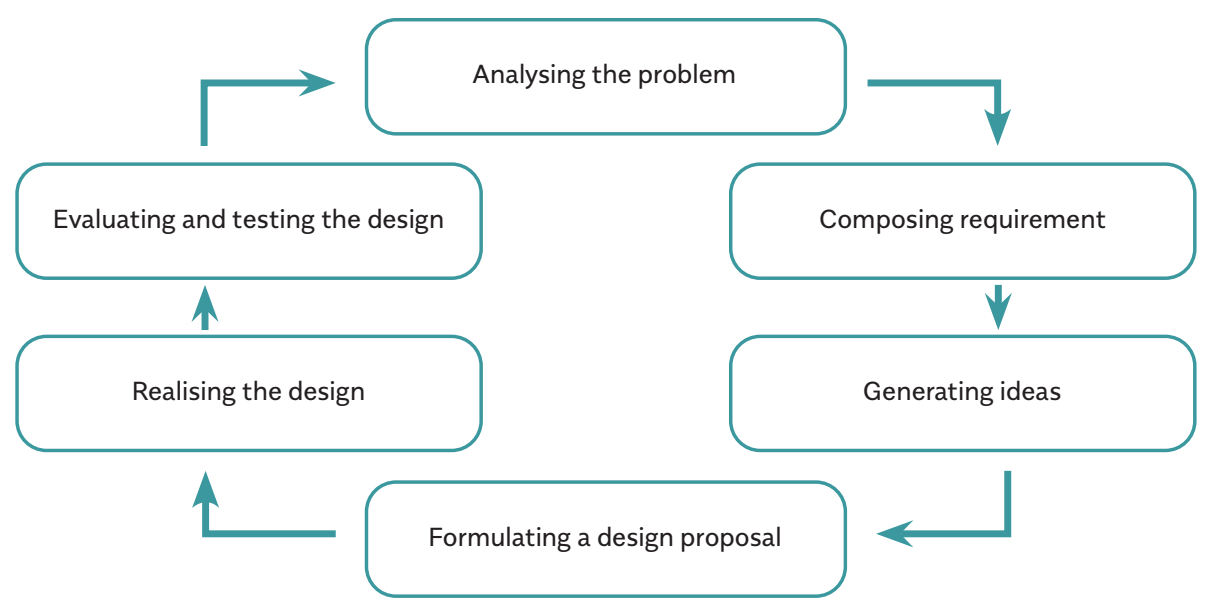

Source: Roozenburg \& Eekels, 1995.

This process entails the following:

1. trace the entire design process with reference to a specific situation ('case study');

2. reflect retrospectively on the process and extrapolation of the model ('mental') as a scaffold for similar activities; 
3. focus attention on specific "segments" of the process to instruct students on how to proceed, e.g. generate ideas, analyze the problem, etc.;

4. finally, retrace the entire design process without referring to such a specific situation as in point 1.

This suggests that, unlike the analytical linear model (ADDIE or Backwards), which always starts from the outcomes and always arrives at the evaluation, the global cyclical model allows the teacher in training first to grasp the underlying process in an intuitive way (1), then encourage a reflective look back at it (2), and finally conduct an analysis of its parts (3) and strengthen the initial intuition (4).

Furthermore, it seems applicable beyond the actual design process proposed (1), which may in fact vary due to basic pedagogy.

Boosting Teacher Quality Report: Pathways to Effective Policies $(E C, 2018)$ underlines that the development of a national framework of teacher skills, considered "high-level learning professionals", is a key element for improving the quality of teaching.

According to this, in addition to working in the learning community of their school, teachers should also be part of wider professional networks - networked schools, "learning ecosystems" at the "meso" level - which allow them to connect and support collective learning and the innovation of teachers beyond their work in individual schools (creation and exchange of knowledge between schools, but also differentiation of roles in terms of career, with expert teachers who take on coordinating roles both inside and outside their school). The new profile of teachers, emerging from international policies, therefore becomes that of a professional capable of working online and collaboratively with colleagues, parents and other professionals (Hammond, 2010; OECD, 2014), of implementing effective interventions (Stronge, 2018) and of making flexible choices and interventions that are responsive to the principle of autonomy (Schleicher, 2016) and differentiated according to the specificities of the contexts and the heterogeneity of the students (Kinsella \& Pitman, 2012).

This remark suggests that in order to train teachers' design skills (Agrati, 2016, 2017), it is necessary, though not sufficient, to provide models (such as "cognitive artifacts"), which are useful for explaining 
processing procedures (e.g. phases: timing, outcomes, instructions, assessing, mediation - see Table 1) and, in terms of effective professionalisation, above all, for encouraging the exchange of knowledge and experiences within a learning community in a real "ecosystem of learning".

\section{Professional courses on design: The European Design case}

Accepting the "challenge" posed by Law No. 107/2015 and PNF/2016 (National Plan of Teacher Training), and in accordance with the international guidelines that underlined the need for an accompaniment to the professionalisation, didactic and methodological innovation and realisation of network projects between schools, families and territories, the University of Bari set up, under the coordination of L. Perla, the DidaSco ${ }^{3}$ project "Services for school teaching and the professional development of teachers" (Perla, Vinci \& Agrati, 2017) in the academic year 2016/2017, a catalogue of professional training courses within the scope of the Third University Mission ${ }^{4}$. As a result of the skills gained during the training, each DidaSco course requires a final production - a "prototype", i.e. an operating device ${ }^{5}$ (a project/piece of work,

DidaSco is a multidisciplinary research group made up of researchers from different disciplines (pedagogy, philosophy, mathematics, history, psychology, sociology) and founded for researchers to meet and study the training needs in services emerging from Italian schools.

University institutions are responsible for ensuring increasingly managerial activities, as well as research and teaching activities (Deem, Hillyard \& Reed, 2007). These activities have a high impact on the territory, as foreseen by the Third University Mission (Serbati, 2014). The concept of the Third Mission - introduced in Italy by ANVUR (National Agency for the Evaluation of the University System and Research) in the VQR 2004-2010 (Evaluation of the Quality of Research) to open "the socio-economic context through the enhancement and transfer of knowledge" - involves giving attention not only to strictly disciplinary and training areas but also to the development of complex skills from pedagogical-didactic, professional, organisational-managerial, managerial and leadership points of view.

The concept of "device" has been the object of reflection in many areas of knowledge, primarily in the philosophical (Foucault, 1976; Agamben, 2006; Deleuze, 2007) and pedagogical ones (Massa, 1992; Barone 1997). From a specifically didactic point of view, the concept of "device" is intended as that which makes possible the structuring of the relationship between the world of the student and the world of the teacher in the didactic action (Rossi, 2009, 2011; Rossi \& Toppano, 2009), as a "network of knowledge mediation" (Berten, 1999), as "what tends to set up an environment in which the relational network between teachers, students and knowledge is configured dynamically and becomes a system" (Parmigiani, 2017), as the "internal organisation of didactic elements" (Damiano, 2006), as a situation designed by the teacher so that students can learn, carry out a task, realize a project, and solve a problem (Magnoler, 2009), and as a cultural, conceptual and normative apparatus/support to guide the dynamics 
an intervention program, a Competence Unit, etc.), developed during the course, which can be concretely experimented with in class in order to "test" what has been learnt.

The DidaSco course "European Design in the school of autonomy" (coordinated by L. Perla and conducted by V. Vinci as expert trainer) is part of the international (Schleicher, 2016; Burns \& Köster, 2016; Eurydice, 2018a, 2018b; EC, 2018; Pieters, Voogt \& Preja Roblin, 2019) and national (Perla, 2016; Perla \& Tempesta, 2016; Perla \& Martini, 2019) professional development trend aimed at system skills - indicated by the PNF/2016 as a "priority" - and didactic and organisational autonomy, which includes some key contents, such as European Design. The course was structured according to the organisational and didactic model common to DidaSco courses (Perla, Vinci \& Agrati, 2017) but customised in content (Annex 1; see also Vinci, 2019). It was conducted in two editions: in 2018 at the "Davanzati-Mastromatteo" School in Palo del Colle (Bari), involving 30 teachers, and in 2019 at the Technical Institute "Vitale Giordano" in Bitonto (Bari), involving 14 teachers.

The choice of the course by the schools was motivated by multiple reasons:

1. The first reason is linked to the analysis of the teachers' training needs, expressed and manifested both in their first contact with the university and during the first training meeting. Teachers are increasingly called upon to strengthen their entrepreneurial ability to use/identify human, financial and technological resources to improve the quality of their teaching, including through external funding sources; to work collaboratively with other teachers and with other professional figures, both inside and outside the school, and therefore to encourage territorial partnerships and participatory planning; to enrich the educational offer with projects based on interdisciplinary knowledge and the development of cross-curricular skills, giving complete fulfillment to the opportunities offered by the real implementation of autonomy and organisational flexibility; and to experiment and implement innovative and laboratory teaching

of knowledge acquisition (Calvani, 2007). As a "bridge between action and its representation", according to Rossi (2011), the device promotes the documentation of the didactic act and the generation of the teachers' pedagogical knowledge. 
and management-organisational models with different temporalspatial modulations and different classroom management;

2. The second reason is the connection with the national and international ${ }^{6}$ professional development trends: the system skills - indicated by the PNF/2016 as a priority of the professional development system - include didactic and organisational autonomy, which includes some key contents ${ }^{7}$, including European Design.

Through a simulated situation ${ }^{8}$ (Samurçay \& Rogalski, 1998; Samurçay, 2005; Vidal-Gomel, 2005; Fauquet, 2006; Fauquet-Alekhine

The internationalisation of education systems and the mobility and recognition of training credits and qualifications are significant issues in European policy documents. For example, the Structural Indicators for Monitoring Education and Training Systems in Europe report (Eurydice, 2018b) highlights, among the European political educational priorities, the improvement of learning mobility. One of the main obstacles to mobility in the field of education, stresses the report, is a lack of sufficient funding, but Europe remedies this with the mobility grants of the Erasmus+ Program. European policy invites Member States to examine, in parallel with direct financial aid, their internal support (Council Recommendation of 28 June 2011 on "Youth on the move" - promoting the learning mobility of young people, OJ C199, 7.7.2011, C199/4) and to recognize, in a coherent way, the learning outcomes acquired through credits (European Credit Transfer and Accumulation System - ECTS) and higher education qualifications.

Designing in the context of autonomy; European design; organisational flexibility; modular teaching; classroom management; participatory design of learning environments; management and enhancement of the share of autonomy of the Institute curriculum; use of autonomy staff: models and simulations; team work; school time; enhanced staff and functional staff; team teaching; peer review and tutoring; role of middle management in the school; work in the professional community; planning of the training offer plan; working in networks and areas (PNF/2016, p. 27).

The "simulator" artifact is represented by a documentary design format, partly developed by the DidaSco group on the basis of theoretical knowledge and models on the subject (Capperucci, 2008; Mastrofini, 2017; Sarracino, 2017) and shared international design experiences with schools, partly co-built with teachers during training meetings, i.e. during the simulation situation. The artifact was built while thinking about the different voices that could somehow guide the teachers in moving from the abstract creative idea to the concrete project (a "project type", not designed for a specific funding announcement) and which are sometimes completely ignored by the teachers, often also in the planning phase. The items used for the European DidaSco design format are: Registry section (name of the project, school data/ network of the proposing school and its components, curriculum and skills); Project section (project objectives, identification of the stakeholders and requirements that meet the needs and expectations of the stakeholders, deliverables (results) of the project, milestones, activity timetable, intermediate results or main deadlines to be respected, hypotheses on the methods of implementation (WP), resources involved (work team), times, financial plan, constraints, risks, dependence on other projects/initiatives, success criteria, manager and work team, monitoring and evaluation, dissemination, follow up, feasibility, sustainability, innovation); and Attachments section. 
\& Labrucherie, 2012; Vidal-Gomel \& Fauquet-Alekhine, 2016), the teachers developed "prototypes" of European projects - a total of five projects, focused on the connection between school and territory, were drawn up. Each project team was composed of teachers differentiated by school level. The design of teaching devices requires four fundamental steps, as Rossi (2009) and Pastré and Samurçay (2004) have suggested: "identification of the action field and analysis of the relative tasks and activities; modeling of the training situation and simulation, carried out by the designer to hypothesise how the recipients will interpret the intrinsic device network; analysis of the skills gained by the subjects in their experience and which are mobilised in the resolution of the task presented in the training situation; analysis of the evolution of knowledge and skills that manifests itself in the path" (Rossi, 2009, p. 214).

Figure 2. Three levels of analysis of simulations adapted from Samurçay

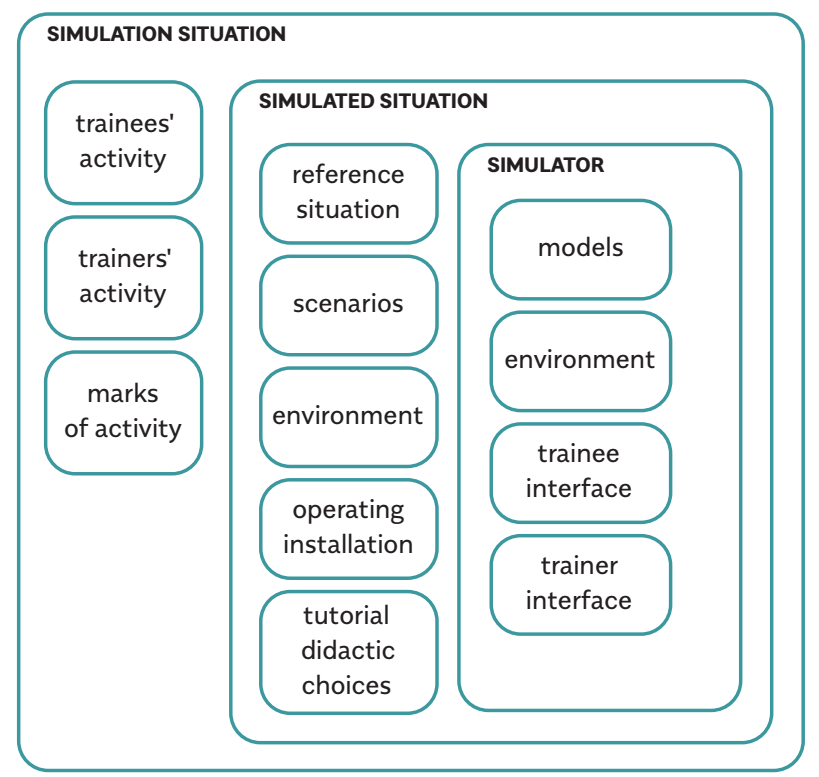

Source: Vidal-Gomel, 2005; Vidal-Gomel \& Fauquet-Alekhine, 2016.

In the "simulation situation" (Vidal-Gomel \& Fauquet-Alekhine, 2016, p. 3), the debriefing plays a key role, which is designed not only at the end of the entire training course, but is used at the end of each meeting/ 
laboratory session, and therefore as a feedback tool, source of constant monitoring and scaffold in the project simulation. In the specific simulation situation, some actions of the trainer carried out during the debriefing phase led to a partial re-elaboration of the design device: the description of some new tools considered by the trainee teacher to be of particular interest and usefulness, such as those aimed at graphic representations and summaries of the most relevant design information (the work breakdown structure, the responsibility matrix, the Gantt diagram, the risk plan, the WP plan, the SWOT analysis matrix); practical-operational advice and information on possible calls for scholastic interest (Erasmus+, Europe for Citizens, FSE-FESR Programming 2014-2020, Horizon, etc.). In the simulation situation, moreover, some operations were carried out to transform the real situation (to elaborate a European project) in order to facilitate the acquisition of skills by the trainee teachers (Samurçay \& Rogalski, 1998): division of tasks and under-tasks between group members, separation of variables (in particular those relating to the calculation of economic resources and therefore the formalisation of the budget, initially separated from the other dimensions planned - due to their technical nature - and subsequently reintegrated) and to focus the relationships between variables (in the matrix of responsibilities, which made it possible to visualise "who does what, when and with what resources", that is, linking human resources, actions, times, and costs). Precise tutoring actions were adopted to support the teachers and to transpose project management knowledge at the school level, as well as by the adaptation and customisation of some standard items to the training needs of a specific school.

\section{Survey on teachers' representations of design}

In 2018-2019, an initial investigation was conducted by the DidaSco Research Group with the aim of learning the representations of design given by the teachers participating in the professional training course "European Design in the school of autonomy" (Vinci, 2019). The study aimed at understanding and fostering the point of view of teachers about teacher's design skills, acknowledging professional knowledge as implicit and pre-reflexive; it referred to teachers' thinking and teachers' professional knowledge studies (Shulman, 1986, 2004; Clark \& Peterson, 1986; Day, Pope \& Denicolo, 1990) and focused on the embedded 
pre-reflexive knowledge of teachers (Stadler \& Frensch, 1998; Calderhead \& Robson, 1991; Cabaroglu \& Roberts, 2000; Gommers \& Hermans, 2003). At the end of the course, the 14 teachers involved answered an ad hoc online questionnaire (Table 2).

Table 2. Characteristics of the involved teachers

\begin{tabular}{l|c|c|c}
\multicolumn{1}{c|}{ GENDER } & AGE (MEAN) & SCHOOL GRADE & QUALIFICATION \\
\hline 11 females & 50.55 years & $\begin{array}{c}\text { Primary } \\
\text { school (2) }\end{array}$ & Master's degree or post-graduate degree (6) \\
\hline 3 males & 47.33 years & $\begin{array}{c}\text { Middle school } \\
(6)\end{array}$ & Bachelor's degree (3) \\
\cline { 3 - 4 } & & $\begin{array}{c}\text { Secondary } \\
\text { school (6) }\end{array}$ & High school diploma (1)
\end{tabular}

All 14 teachers ( 3 males, 11 females) were also referents for specific areas of managing school institutions, such as legality, orientation, digital technology, three-year plan of training offers ${ }^{9}$, evaluations, and teacher training. The questionnaire was structured in seven openended questions:

1. How would you define the word "design"?

2. Write three words that you associate with "design".

3. Reflecting on the simulation experience of drawing up a project, what were the greatest difficulties encountered?

4. Reflecting on the simulation experience of drawing up a project, what kind of relational dynamics were generated in the group?

5. Do you think the simulation experience was useful? If so, in what way?

6. What skills do you think you have acquired since the course?

7. In relation to design skills, on what do you think you need further training?

$9 \quad$ The three-year plan of training offer (PTOF) complies with the provisions of Art. 1 of Italian Law No. 107 of 13 July 2015. The PTOF is the basic constitutive document of the cultural and organisational identity of the educational institutes which presents the curricular, extracurricular, and didactic and organisation plans that schools adopt thanks to their autonomy. It is normally developed and updated every year, based on the social, cultural, educational and demographic characteristics of the context. In order to allow a comparative evaluation by students and families, and to ensure full transparency and promotion, the PTOF is published on the school's web portal. 
The answers were analysed inductively through the emerging categories method (Q.1) and textual analysis software (Q.2). The questionnaire data was also used to monitor the impact of the professional training course on knowledge and to deduce possible descriptors of the quality of knowledge/design skills. About half of the respondent teachers defined the word "design" (see Q.1) as a transformative process, e.g. "Designing means starting from the analysis of the existing to project towards the future, towards the identification of hypothetical paths of the transformation of reality"; "Starting from the existing and identifying paths of change of reality". Some teachers underline, on the other hand, the importance of the creative dimension: "Creative activity that must be translated into activity"; "Elaboration of a creative idea"; "Breeding ground of ideas". Others define it as planning and structuring a work path: "Timely planning of a work path"; "To give shape and structure to an idea so that it can be implemented".

Regarding associations with the word "design" (Q.2), the analysis of the occurrences - as shown in Table 3 and the word-cloud (Figure 3) - highlights the link with the concept of planning (i.e. of activities) and ideation.

Table 3. Word list: design

\begin{tabular}{c|c} 
WORD & WEIGHT \\
\hline Plan/planning & 4 \\
\hline Idea/ideation & 4 \\
\hline Contextualized & 2 \\
\hline Feasibility & 2 \\
\hline Intentional & 2 \\
\hline Organisation & 2 \\
\hline Elaborate/elaboration & 2 \\
\hline Evaluate/evaluation & 2 \\
\hline
\end{tabular}

Figure 3. Word-cloud: design

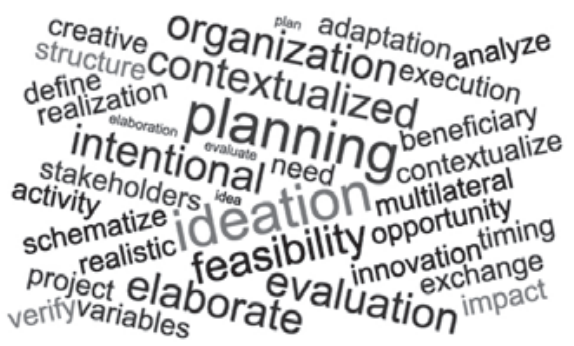

The difficulties encountered in the simulation experience of design (Q.3) were of different types: from temporal - e.g. little time available ("having little time, dealing with the complexity of the concrete situation"), timing ("to assume a realistic and precise time schedule") - to financial issues ("implement a rigorous financial plan"); from 
the relationship with stakeholders ("identify the needs of stakeholders") to the reporting for the territory ("explain the impact of the project on the territory"); from the drafting of a risk plan ("foreseeing risks and criticalities"; "write a risk plan") to the generalisation of the effects ("broaden the project horizons to give it a wider scope"); and from the lack of explanatory examples ("not having a concrete example of a project call to refer to") to the choice of useful measures ("designing really useful measures").

The relationship dynamics generated in the group during the simulation experience of drawing up a project (Q.4) were very positive, based on comparisons, the negotiation of solutions, the sharing of proposals, teamwork, and interdependence. The importance of "vertical" confrontations with colleagues from different grades of schools was stressed:

[It] allowed me to deal with different realities from the one in which

I work. This has broadened my horizons and allowed me to work vertically, enriching my knowledge thanks to the experiences of those who have already carried out projects in their school.

Twelve teachers considered the simulation experience useful (Q.5) because it offered the possibility of collaborating in a team, meeting colleagues from different schools and different school grades, getting into concrete situations, reflecting on the complexity of developing a project and on the risks that may arise in the project implementation phase, thinking of strategies to solve problems, and understanding that "even the brightest ideas, in comparison with the group, are perfected".

The last two questions (Q.6, Q.7) were very useful for understanding outcomes and needs from the teachers' point of view and redesigning the next professional training courses. 
Table 4. Outcomes and needs of teachers

\begin{tabular}{|c|c|}
\hline OUTCOMES & NEEDS \\
\hline $\begin{array}{l}\rightarrow \text { Working in a team, collaborating in a team, } \\
\text { communicating and relating to people } \\
\text { from different backgrounds; } \\
\rightarrow \text { Organisational and managerial skills, } \\
\text { economic management; } \\
\rightarrow \text { Monitoring and research skills } \\
\text { from project partners. }\end{array}$ & $\begin{aligned} & \rightarrow \text { Knowledge - information on project } \\
& \text { calls (Erasmus+); information on current } \\
& \text { legislation; analysis of existing and } \\
& \text { well-structured projects (concrete } \\
& \text { examples), listening to expert witnesses } \\
& \text { on the difficulties encountered, } \\
& \text { knowledge of previous experiences; } \\
& \rightarrow \text { Procedures - drafting of the budget and } \\
& \text { reporting (project reporting/documentation); } \\
& \rightarrow \text { Processes - methodology and project } \\
& \text { monitoring criteria, in the short, medium and } \\
& \text { long term; identification of the strengths/ } \\
& \text { weaknesses of the project; risk management. }\end{aligned}$ \\
\hline
\end{tabular}

Summarising the data analysis, teachers define the word "design" as a transformative process, underlining the importance of several dimensions, like creativity, planning, structure, context, feasibility, intentionality, organisation, elaboration, and evaluation. Therefore, the results of the study allowed the most significant meanings of such a complex theme to be deepened, such as the enhancement of learning design, with the group of teachers involved in the training. This theme can be translated into effective practices in the simulation experience of design. As we have seen, the relationship dynamics generated in the group during the simulation experience of drawing up a project were very positive, based on comparisons, the negotiation of solutions, the sharing of proposals, teamwork, and interdependence. Teachers considered the simulation experience to be useful because it offered them the possibility of collaborating with colleagues from different schools and different school grades, getting into concrete situations, reflecting on the complexity of developing a project, and thinking of strategies to solve problems. The outcomes, in fact, indicate managerial, communication, economic, evaluation and research skills: the outgoing professional profile is certainly rich, complex, and flexible, as required by the most recent international policies. Many difficulties were encountered in the simulation experience of design, among which were the short time available, the lack of explanatory examples, and the drafting of plans that involve consolidated concrete experiences (e.g. risk plan, financial plan). Training needs concern both the field of knowledge and that of procedures and processes 
(see Table 4). These responses suggest a need to implement training courses in which experiences, simulations and procedural knowledge are enhanced. Finally, the experiences mentioned revealed a different mastery in the elaboration of a European project by the teachers: all of this shows the heterogeneity of the skills of the trainee teachers and a general difficulty in concretely elaborating, from a technical and operational perspective, the creative idea behind the project (which remains very generic).

\section{Findings and conclusion}

The theoretical framework and the findings of the investigation make it possible to advance a series of reflections regarding the typical procedure for training in design skills. This procedure could be inspired by the "cyclical process", admit the training modality of the simulated experience and, last but not least, be open to a learning ecosystem.

There should be a procedure for training the very complex design skill of teachers (Fredrick \& Sonneveld, 2009; Roozenburg \& Eekels, 1995), assuming a sort of scheme with "stable" components - such as the choice of learning outcomes and instructions, as well as assessment methods (see Table 1; see also Branson et al., 1975; Dick et al., 2005), although the latter are sometimes inverted (Wiggins \& McTighe, 1998), or specific components, such as timing and mediation (Dick et al., 2005; Fink, 2003). This scheme could be guaranteed on a qualitative level if were carried out in a "cyclical" way (see Figure 1) through the passage from Analysing the problem, to Formulating a design proposal (the actual "design"), to the Testing of the design, and returning to Analysing the problem.

As highlighted by the investigation on simulation experience, although teachers are sure that, from a theoretical point of view, the design is, in other words, a "plan" (Q.1), they nevertheless feel the difficulty of translating these hypotheses in concrete situations, both temporally and materially (Q.3). It seems that teachers have the structure but lack concrete references to implement, above all, the transition from Formulating a design proposal to Realising the design; also, for this reason, they firmly asked for concrete design examples and witnesses that can describe the experience.

Other difficulties have been expressed regarding the risk assessment and the generalisation of the effects (Q.3), aspects that - compared 
to the "cyclical process" - are associated with Evaluating and testing the design and, in particular, the passage from this to Analysing the problem.

These aspects allow us to argue that, although we are in possession of explanatory models of the entire quality process - as illustrated in Figure 1 - we should direct our investigations to better describe the passage from one moment to another and how this could be favored.

As described in the previous paragraphs, the teaching strategy used in the course on European planning was the simulation experience, realized, in particular, through debriefing and structuring the groups for tasks and sub-tasks. Re-reading the survey responses, it is as if the operational difficulties reported in Q.3 (especially the lack of additional examples) were partially recovered thanks to the presence of colleagues, with whom the teachers had the opportunity to "broaden their horizons", to discuss solutions, to externalize their fields of experience (including referring to unknown school degrees, different from one's own), and even to critically reflect on the effective usefulness of certain procedures adopted (Q.4, Q.5).

Recourse to the working group, as a peer, within the simulation experiences was confirmed to be a positive aspect; it should be taken into consideration when carrying out professional training programs for teachers, as, among other things, is already highlighted in the literature - on support environments within schools and networks for teacher collaboration, the sharing of professional standards and the co-construction of functional artifacts for teaching-learning processes (Seashore, Marks \& Kruse, 1996; Toole \& Louis, 2002; Thompson, Gregg \& Niska, 2004; Stoll et al., 2006; Lisse, Swets, Zeitlinger Stoll \& Louis, 2007; Donner, Mandzuk \& Clifton, 2008) - and the European document on the Professional Learning Community (EC, 2018, p. 55).

The last reflection concerns the emerging learning ecosystem. As is known, this refers to the ability, as well as the willingness, to feel part of a much wider learning system, within which teachers could occupy the middle part since it deals with favoring the passages from the center (the policies and choices of schools) to the final "terminals" - i.e. families and students (Hammond, 2010; OECD, 2014).

This awareness clearly emerged in the investigation since teachers highlighted, on the one hand, the difficulties in entering into an adequate relationship with the needs of the stakeholders and in reporting 
the outcomes for the territory, and, on the other, the need to share work experiences in the group that would allow them to extend boundaries and open up to other dimensions such as the "vertical" one, thanks to them sharing with colleagues of other school grades (see Q.3, Q.5).

This could be a sign of a new way of being a teacher that responds to the new profile of a teacher that is emerging from international policies (Schleicher, 2018), one who is willing to collaborate with colleagues, interpret the needs of the outside world (stakeholders, families, other entities) and adopt flexible choices and interventions, and who, within this way of being, gives proof of their autonomy and strong professionalism (Schleicher, 2016).

\section{References}

$\rightarrow$ Agamben, G. (2006). Che cos'è un dispositivo?. Roma: Nottetempo.

$\rightarrow$ Agrati, L.S. (2016). La competenza progettuale dell'insegnante. Esplicitazione della componente abduttiva, Formazione \& Insegnamento, XIV(3), 155-164.

$\rightarrow$ Agrati, L.S. (2017). La competenza progettuale dell'insegnante. L'analisi dei project work. In: P. Magnoler, A.M. Notti, L. Perla (eds.), La professionalità degli insegnanti. La ricerca e le pratiche (pp. 779-792). Lecce: Pensa Multimedia.

$\rightarrow$ Barone, P. (1997). La materialità educativa. L'orizzonte materialista dell'epistemologia pedagogica e la clinica della formazione. Milano: Unicopli.

$\rightarrow$ Berten, A. (1999). Dispositif, médiation, créativité: Petite génealogie. Paris: CNRS Education.

$\rightarrow$ Bowen, G.A. (2009). Document Analysis as a Qualitative Research Method, Qualitative Research Journal, 9(2), 27-40.

$\rightarrow$ Branson, R.K., Rayner, G.T., Cox, J.L., Furman, J.P., King, F.J. and Hannum, W.H. (1975). Interservice procedures for instructional systems development. Ft. Monroe: U.S. Army Training and Doctrine Command.

$\rightarrow$ Britain, S. (2004), A Review of Learning Design: Concept, Specifications and Tools. A report for the JISC E-learning Pedagogy Programme.

$\rightarrow$ Burns, T. and Köster, F. (eds.) (2016). Governing Education in a Complex World. Paris: Organisation for Economic Co-operation and Development Publishing.

$\rightarrow$ Cabaroglu, N. and Roberts, J. (2000). Developments in student teachers' preexisting beliefs during a one-year P.G.C.E. programme, System, 28(3), 387-402.

$\rightarrow$ Calderhead, J. and Robson, M. (1991). Images of Teaching: Student Teachers' Early Conceptions of Classroom Practice, Teaching and Teacher Education, $7(1), 1-8$. 
$\rightarrow$ Calvani, A. (2007). Fondamenti di didattica. Teoria e prassi dei dispositivi formative. Roma: Carocci.

$\rightarrow$ Capperucci, D. (2008). Dalla programmazione educativa e didattica alla progettazione curricolare. Modelli teorici e proposte operative per la scuola delle competenze. Milano: FrancoAngeli.

$\rightarrow$ Clark, C.M. and Peterson, P.L. (1986). Teachers' Thought Process, In: M.C. Wittrock (ed.), Handbook of Research on Teaching. New York: MacMillan.

$\rightarrow$ Council Recommendation of 28 June 2011 on "Youth on the move" - promoting the learning mobility of young people, OJ C199, 7.7.2011, C199/4.

$\rightarrow$ Damiano, E. (2006), La Nuova Alleanza. Temi problemi e prospettive della nuova ricerca didattica, Brescia: La Scuola.

$\rightarrow$ Day, C., Pope, M. and Denicolo, P. (1990). Insights into Teachers'Thinking and Practice. London: Palmer Press.

$\rightarrow$ Deem, R., Hillyard, S. and Reed, M. (2007). Knowledge, Higher Education, and the New Managerialism. The Changing Management of UK Universities. Oxford: Oxford University Press.

$\rightarrow$ Deleuze, G. (2007). Che cos'è un dispositivo? Napoli: Cronopio.

$\rightarrow$ Dick, W., Carey, L. and Carey, J.O. (2005). The systematic design of instruction. Boston: Allyn and Bacon.

$\rightarrow$ Donner, A., Mandzuk, D. and Clifton, R.A. (2008). Stages of Collaboration and the Realities of Professional Learning Communities, Teaching and Teacher Education, 24, 564-574.

$\rightarrow$ European Commission (2011). Entrepreneurship Education: Enabling Teachers as a Critical Success Factor. A report on Teacher Education and Training to prepare teachers for the challenge of entrepreneurship education. Luxembourg: European Commission, DG Enterprise and Industry.

$\rightarrow$ European Commission (2013). Supporting teacher competence development, http://ec.europa.eu/ education/policy/school/doc/teachercomp_en.pdf.

$\rightarrow$ European Commission (2018). Boosting teacher quality: pathways to effective policies. Luxembourg: European Commission.

$\rightarrow$ Eurydice (2018a). Teaching Careers in Europe: Access, Progression and Support. Bruxelles: European Commission.

$\rightarrow$ Eurydice (2018b). Structural Indicators for Monitoring Education and Training Systems in Europe. Bruxelles: European Commission.

$\rightarrow$ Fauquet-Alekhine, Ph. and Labrucherie, M. (2012). Simulation training debriefing as a work activity analysis tool: the case of nuclear reactor pilots and civil aircraft pilots. In: Ph. Fauquet-Alekhine (ed.), Socio-organisational factors for safe nuclear operation (pp. 79-83). Montagret: Larsen Science. 
$\rightarrow$ Fauquet, Ph. (2006). Confrontation croisée ou analyse collective sur la base de restitutions d'entretiens individuels: Deux approches pour l'analyse évènementielle, Revue électronique @ctivités, 3(2), 2-14.

$\rightarrow$ Fink, L. (2003). Creating Significant Learning Experiences for College Classrooms: An Integrated Approach to Designing College Courses. San Francisco: Jossey-Bass.

$\rightarrow$ Foucault, M. (1976). La volontà di sapere. Milano: Feltrinelli.

$\rightarrow$ Frederik, J.E. and Sonneveld, W. (2007). Mysteries for sale. In: M.J. de Vries, R. Custer, J. Dakers, G.E. Martin (eds.), Analyzing best practices in technology education (pp. 83-92). Rotterdam/Taipei: Sense Publishers.

$\rightarrow$ Frederik, I. and Sonneveld W. (2009). Teaching design skill: Technology in senior secondary education. In: A. Bekker, I. Mottier, M.J. de Vries (eds.), Proceedings PATT-22 Conference: Strengthening the position of technology education in the curriculum (pp. 218-225). Delft: International Technology and Engineering Educators Association.

$\rightarrow$ Freiberg, H.J. (2002). Essential skills for new teachers, Educational Leadership, 59(6), 56-60.

$\rightarrow$ Gommers, L. and Hermans, C. (2003). Beliefs in action: Teachers' identity influences school's identity, International Journal of Education \& Religion, 4(2), 186-198.

$\rightarrow$ Hammond, K.R. (2010). Intuition, no!... Quasirationality, yes!, Psychological Inquiry, 21, 327-337.

$\rightarrow$ Hornby, A.S. (ed.) (2010). Oxford Advanced Learner's Dictionary of Current English ( $8^{\text {th }}$ ed.), Oxford: Oxford University Press.

$\rightarrow$ Kinsella, A.E and Pitman, A. (eds.) (2012). Phronesis as professional knowledge - practical wisdom and the professions. Rotterdam: Sense Publishers.

$\rightarrow$ Koper, R. (2006). Current Research in Learning Design, Educational Technology \& Society, 9(1), 13-22.

$\rightarrow$ Laurillard, D. (2012). Teaching as a design science. Building pedagogical patterns for learning and technology. New York-London: Routledge.

$\rightarrow$ Law 13/07/2015, No. 107. European Commission, 2013.

$\rightarrow$ Lisse, N.L., Swets, L., Zeitlinger Stoll, L. and Louis, K.S. (2007). Professional Learning Communities: Elaborating New Approaches. In: L. Stoll, K.S. Louis (eds.), Professional Learning Communities: Divergence, Depth, and Dilemmas (pp. 1-14). Berkshire: Open University Press.

$\rightarrow$ Loughran, J.J. (2006). Developing a pedagogy of teacher education: Understanding teaching and learning about teaching. London: Routledge. 
$\rightarrow$ Magnoler, P. (2009). I dispositivi didattici e l'on line. In: P.G. Rossi, Tecnologia e costruzione di mondi (pp. 206-254). Roma: Armando.

$\rightarrow$ Mantyla, K. (1999), Interactive distance learning exercises that really work! Alexandria: American Society for Training and Development.

$\rightarrow$ Massa, R. (ed.) (1992). La clinica della formazione. Un'esperienza di ricerca. Milano: Unicopli.

$\rightarrow$ Mastrofini, E. (2017). Guida alle conoscenze di gestione progetti. Griglia di riferimento per i responsabili di progetto e per gli altri ruoli professionali di project management. Milano: FrancoAngeli.

$\rightarrow$ Nikolaeva, S. (2012). Improving initial teacher education by using the projectbased approach, Educational Research e-Journal, 1(1), 51-60.

$\rightarrow$ OECD (2009). TALIS - The OECD Teaching and Learning International.

$\rightarrow$ OECD (2014). Education at a Glance 2014: OECD Indicators.

$\rightarrow$ Parmigiani, F. (2017). Dispositivi, ambienti, artefatti. In: P.C. Rivoltella, P.G. Rossi, L'agire didattico. Manuale per l'insegnante (pp. 231-246). Brescia: La ScuolaMorcelliana.

$\rightarrow$ Pastré, P. and Samurçay, R. (2004). Researches en didactique professionnelle. Toulouse: Octarès.

$\rightarrow$ Perla, L. (2015). Lo sviluppo professionale dell'insegnante. Ipotesi per una modellistica in fiery, Mizar, 1, 9-21.

$\rightarrow$ Perla, L. and Martini, B. (eds.) (2019). Professione insegnante. Idee e modelli di formazione. Milano: FrancoAngeli.

$\rightarrow$ Perla, L. and Tempesta M. (eds.) (2016). Teacher Education in Puglia. Università e Scuola per lo sviluppo della professionalità docente. Lecce: Pensa Multimedia.

$\rightarrow$ Perla, L., Vinci, V. and Agrati, L. (2017). The DidaSco Project: a training program for the teachers' professional development. In: J. Mena, A. García Valcarcel Muñoz Repiso, F.J. García Peñalvo, M. Martín del Pozo (eds.), Search and research: teacher education for contemporary contexts (pp. 921-930). Salamanca: Ediciones Universidad de Salamanca.

$\rightarrow$ Pieters, J., Voogt, J. and Preja Roblin, N. (2019). Collaborative Curriculum Design for Sustainable Innovation and Teacher Learning. Cham: Springer.

$\rightarrow$ Reiser, R.A. and Dempsey, J.V. (2012). Trends and issues in instructional design and technology. Boston: Pearson.

$\rightarrow$ Roozenburg, M. and Eekels, J. (1995). Product Design: Fundamentals and Methods. New York: Wiley.

$\rightarrow$ Rossi, P.G. (2009). Tecnologia e costruzione di mondi. Post-costruttivismo, linguaggi e ambienti di apprendimento. Roma: Armando. 
$\rightarrow$ Rossi, P.G. (2011). Didattica enattiva. Complessità, teorie dell'azione, professionalità docente. Milano: FrancoAngeli.

$\rightarrow$ Rossi, P.G. and Toppano, E. (2009). Progettare nella società della conoscenza. Roma: Carocci.

$\rightarrow$ Samurçay, R. (2005). Concevoir des situations simulées pour la formation professionnelle: Une approche didactique. In: P. Pastré (ed.), Apprendre par la simulation. De l'analyse du travail aux apprentissages professionnels (pp. 221-239). Toulouse: Octarès.

$\rightarrow$ Samurçay, R. and Rogalski, J. (1998). Exploitation didactique des situations de simulation, Le Travail Humain, 61(4), 333-339.

$\rightarrow$ Sarracino, F. (2017). La progettazione didattica come risposta alla complessità della classe. In: P.C. Rivoltella, P.G. Rossi (eds.), L'agire didattico. Manuale per I'insegnante (pp. 209-230). Brescia: La Scuola-Morcelliana.

$\rightarrow$ Schleicher, A. (2016). Teaching excellence through Professional Learning and Policy Reform: Lessons from Around the World, International Summit on the Teaching Profession. Paris: Organisation for Economic Cooperation and Development Publishing.

$\rightarrow$ Schleicher, A. (2018). Valuing our Teachers and Raising their Status: How Communities Can Help. Paris: OECD Publishing.

$\rightarrow$ Seashore, K.R., Marks, H.M. and Kruse, S. (1996). Teachers' Professional Community in Restructuring Schools, American Educational Research Journal, 33(4), 757-798.

$\rightarrow$ Serbati, A. (2014). La terza missione dell'università. Riconoscere apprendimenti esperienziali e certificare competenze degli adulti. Lecce: PensaMultimedia.

$\rightarrow$ Shulman, L.S. (1986). Those who understand: knowledge growth in teaching, Educational Researcher, 15(2), 4-14.

$\rightarrow$ Shulman, L.S. (2004). The Wisdom of Practice: Essays on Teaching, Learning, and Learning to Teach. San Francisco: Jossey-Bass.

$\rightarrow$ Skinner, B.F. (1954). The Science of Learning and the Art of Teaching, Harvard Educational Review, 24(2), 86-97.

$\rightarrow$ Snelbecker, G.E. (1987). Instructional design skills for classroom teachers, Journal of Instructional Development, 10(33), 33-40.

$\rightarrow$ Stadler, M.A. and Frensch, P.A. (eds.) (1998). Handbook of implicit learning. London: Sage Publications.

$\rightarrow$ Stoll, L., Bolam, R., McMahon, A., Wallace, M. and Thomas, S. (2006). Professional Learning Communities: A Review of the Literature, Journal of Educational Change, 7(4), 221-258.

$\rightarrow$ Stronge, J.H. (2018). Qualities of effective teachers. Alexandria: ASCD. 
$\rightarrow$ Taba, H. (1962). Curriculum. Development, Theory and Practice. New York: Harcourt Brace \& World.

$\rightarrow$ Thompson, S.C., Gregg, L. and Niska, J.M. (2004). Professional Learning Communities, Leadership, and Student Learning, Research in Middle Level Education Online, 28, 1-15.

$\rightarrow$ Toole, J. and Louis, K.S. (2002). The Role of Professional Learning Communities in International Education. In: K. Leithwood, P. Hallinger, The Second International Handbook of Educational Leadership (pp. 245-279). Dordrecht: Kluwer.

$\rightarrow$ Vidal-Gomel, C. (2005). Une approche prélable à l'analyse de l'activité et des competences, Éducation Permanente, 165, 47-68.

$\rightarrow$ Vidal-Gomel, C. and Fauquet-Alekhine, P. (2016). Reflections and Theoretical Contributions Regarding Trainers' Practice and Simulation. In: P. Fauquet-Alekhine, N. Pehuet (eds.), Simulation Training: Fundamentals and Applications (pp. 1-29). London: Springer.

$\rightarrow$ Vinci, V. (2019), Le competenze progettuali degli insegnanti nella scuola dell'autonomia: analisi dei prototipi di un corso di sviluppo professionale DidaSco. In: L. Perla, B. Martini, Professione insegnante. Idee e modelli di formazione (pp. 178-203). Milano: FrancoAngeli.

$\rightarrow$ Wiggins, G. and McTighe, J. (1998). Understanding by design. Alexandria: ASCD.

$\rightarrow$ Wiggins, G. and McTighe, J. (2008). Put Understanding First, Educational Leadership, 65(8), 35-41. 


\section{Annex}

\begin{tabular}{|c|c|}
\hline $\begin{array}{l}\text { PRIORITY } \\
\text { (CFR. PNF) }\end{array}$ & $\begin{array}{c}\text { SYSTEM EXPERTISE } \\
\text { EDUCATIONAL AND ORGANISATIONAL AUTONOMY }\end{array}$ \\
\hline TITLE & European Design in the school of autonomy \\
\hline PURPOSE & $\begin{array}{l}\text { Ensure that the European Design become a established practice within } \\
\text { the autonomy of the school, developing teachers in methodological construction } \\
\text { of design processes to get out the schools from self-reference and build up } \\
\text { networks of schools and territorial authorities. }\end{array}$ \\
\hline GOALS & $\begin{aligned} \rightarrow & \text { Provide appropriate tools to deal with the extremely competitive market, } \\
& \text { i.e. the "Fundraising" in the field of European Design } \\
\rightarrow & \text { Develop the teachers in the abilities of design, implement } \\
& \text { and manage a European project } \\
\rightarrow & \text { Stimulate the practical application and implementation } \\
& \text { of the knowledge acquired during the course }\end{aligned}$ \\
\hline PROGRAMME & $\begin{array}{l}\text { Activities in presence ( } 8 \text { hours) } \\
\rightarrow \text { Starting a European project } \\
\text { Overview of European funding programmes and knowledge } \\
\text { of the Participant Portal of the European Commission } \\
\text { How to choose call and topic } \\
\text { How to build strategic partnerships } \\
\text { Analyse an application form } \\
\text { Team building } \\
\text { Case studies: presentation of approved European projects } \\
\rightarrow \text { Building a European project: defining the steps leading to the drawing up } \\
\text { an application for eligible and quality funding } \\
\text { Construction of the partnership network and how to connect it } \\
\text { with the services and the territory } \\
\text { Initial survey, analysis of the needs of the context in which the intervention } \\
\text { is inserted and connection with other projects } \\
\text { Work methodology and schedule of activities: objectives, phases, activities, } \\
\text { methods, tools, times, resources } \\
\text { Building a financial budget } \\
\text { Monitoring and evaluation tools of the project idea: construction } \\
\text { of a Quality assurance plan } \\
\text { Dissemination: methods and tools for the dissemination of results } \\
\text { Follow up and project development proposals } \\
\text { Feasibility, sustainability and innovation of a design idea } \\
\text { From the proposal to the financing: the administrative management of the project } \\
\text { Management of co-financing between the partners and the lead entity }\end{array}$ \\
\hline
\end{tabular}

\section{Collaborative / network work * (8 hours)}

The teachers, divided into groups, will participate in laboratory activities in which they will be invited to analyse funding programmes, to identify an application form and to define the actions for the preparation of a hypothetical application for funding. 


\begin{tabular}{|c|c|c|}
\hline & \multicolumn{2}{|c|}{$\begin{array}{l}\text { Research in the classroom* (Prototype) / Documentation* ( } 9 \text { hours) } \\
\text { Development/implementation of a prototype, that is to say a final operating } \\
\text { device, tangible outcome of the skills acquired during the training, to be tested } \\
\text { in teaching practice at school: simulation of the design of a European project } \\
\text { within a working team. } \\
\text { Self-study ( } 25 \text { hours) } \\
\text { * Training activities with a high experimental and practical content (D.M. 509 / 1999) }\end{array}$} \\
\hline LOCATION & \multicolumn{2}{|c|}{ For.Psi.Com. Department University of Bari / Schools } \\
\hline PERIOD & \multicolumn{2}{|c|}{ School years 2016/2017 - 2017/2018-2018/2019 } \\
\hline $\begin{array}{l}\text { DURATION } \\
\text { IN HOURS }\end{array}$ & \multicolumn{2}{|l|}{50 hours } \\
\hline \multirow[t]{6}{*}{ RECIPIENTS } & HEAD TEACHERS & $\mathbf{x}$ \\
\hline & TEACHERS & $\mathbf{x}$ \\
\hline & TEACHERS OF PRIMARY SCHOOL & $\mathbf{x}$ \\
\hline & $\begin{array}{l}\text { SECONDARY SCHOOL TEACHERS } \\
\text { FIRST GRADE }\end{array}$ & $\mathbf{x}$ \\
\hline & $\begin{array}{l}\text { SECONDARY SCHOOL TEACHERS } \\
\text { SECOND GRADE }\end{array}$ & $\mathbf{x}$ \\
\hline & CANDIDATES TO TEACHING & $\mathbf{x}$ \\
\hline \multirow[t]{7}{*}{$\begin{array}{l}\text { METHODOLO- } \\
\text { GIES }\end{array}$} & \multicolumn{2}{|c|}{$\begin{array}{l}\text { The didactic model of reference previews activities in presence } \\
\text { as training modality in which web based learning and blended learning } \\
\text { are integrated. The trainee will have at his disposal all the didactic tools } \\
\text { developed by the teachers of the course: teaching material specially } \\
\text { crafted (lecture notes, documents, glossary, web references). }\end{array}$} \\
\hline & CLASSROOM - FRONTAL LESSONS & $\mathbf{x}$ \\
\hline & CLASSROOM - GROUP WORK & $\mathbf{x}$ \\
\hline & WORKSHOPS & $\mathbf{x}$ \\
\hline & E-LEARNING & $\mathbf{x}$ \\
\hline & WEBINAR & \\
\hline & BLENDED & $\mathbf{x}$ \\
\hline $\begin{array}{l}\text { ORGANISA- } \\
\text { TION }\end{array}$ & \multicolumn{2}{|c|}{$\begin{array}{l}\text { The course will be divided into: } \\
\rightarrow \text { activities in presence, to offer a theoretical frame of reference } \\
\text { and provide insights for personal reflection; } \\
\rightarrow \text { collaborative work / networked to initiate processes for the construction } \\
\text { of competence assessment devices from the theoretical inputs and } \\
\text { the contribution of the comparison with the group (training activities } \\
\text { with a high experimental/practical content); } \\
\rightarrow \text { individual study / experimentation in teaching practice; } \\
\rightarrow \text { e-learning with dedicated moodle platform. }\end{array}$} \\
\hline
\end{tabular}




\begin{tabular}{|c|c|}
\hline $\begin{array}{l}\text { TYPE } \\
\text { OF } \\
\text { FINAL } \\
\text { TESTING }\end{array}$ & $\begin{array}{l}\text { There are two types of tests, using multiple-response tests: } \\
\rightarrow \text { final verification (assessment of knowledge/ skills acquired); } \\
\rightarrow \text { Customer Satisfaction (assessment of course approval level). }\end{array}$ \\
\hline $\begin{array}{l}\text { TYPE OF } \\
\text { DOCUMENTA- } \\
\text { TION / } \\
\text { REPORTING }\end{array}$ & Return of results of research carried out in the class/es. \\
\hline $\begin{array}{l}\text { SKILLS } \\
\text { MAPPING }\end{array}$ & $\begin{array}{l}\rightarrow \text { "Fundraising" skills: being able to analyse the market for European funding, being } \\
\text { able to analyse the needs and motivations which feed the demand for training, } \\
\text { being able to identify calls and topics on which to apply for funding; } \\
\rightarrow \text { "Project management" skills: know how to turn a design proposal into } \\
\text { a sustainable project in which all stages of project implementation and } \\
\text { management are carefully planned; } \\
\rightarrow \text { "Team working, problem solving e management" skills: being able to work } \\
\text { as a team, building on the individual knowledge and skills of colleagues, know- } \\
\text {-how to handle complex situations and any problems or unexpected. }\end{array}$ \\
\hline $\begin{array}{l}\text { PROJECT } \\
\text { TEAM }\end{array}$ & $\begin{array}{l}\text { Course leader: prof. Loredana Perla } \\
\text { Trainer: Viviana Vinci }\end{array}$ \\
\hline $\begin{array}{l}\text { FINAL } \\
\text { CERTIFICATE }\end{array}$ & $\begin{array}{l}\text { At the end of the course a certificate of participation corresponding to the CFU } \\
\text { (university training credits) will be delivered, issued by the University of Bari, } \\
\text { as a qualified subject recognized by the Ministry of Education. }\end{array}$ \\
\hline
\end{tabular}

